\title{
Migren Hastalığının Patogenezinde Oksidatif Stres, Damar Fizyopatolojisini Etkileyen Faktörler ve Enflamasyonun Rolü
}

\section{Role of oxidative stress, factors affecting vascular physiopathology and inflammation in the pathogenesis of migraine disease}

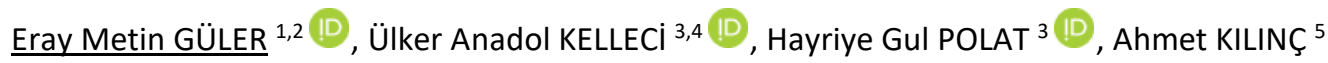 \\ A. Destina YALÇIN ${ }^{3}$ (D) A. Süha YALÇIN 5,6
}

\begin{abstract}
${ }^{1}$ Sağlık Bilimleri Üniversitesi, Hamidiye Tıp Fakültesi, Tıbbi Biyokimya Ana Bilim Dalı, Üsküdar, İstanbul, TÜRKiYE
${ }^{2}$ Sağlık Bilimleri Üniversitesi, Haydarpaşa Numune Sağlık Uygulama Araştırma Merkezi, Tıbbi Biyokimya Ana Bilim Dalı, Üsküdar, İstanbul, TÜRKIYE

${ }^{3}$ Sağlık Bilimleri Üniversitesi, Ümraniye Sağıık Uygulama Araştırma Merkezi, Nöroloji Kliniği, Ümraniye, İstanbul, TÜRKiYE

${ }^{4}$ Özel Kudret International Hospital Nöroloji Bölümü, Maltepe, Ankara, TÜRKiYE

${ }^{5}$ Oksante Ar-Ge Laboratuvarı, TÜRKIYE

${ }^{6}$ Marmara Üniversitesi, Tıp Fakültesi, Tıbbi Biyokimya Ana Bilim Dalı, Maltepe, İstanbul, TÜRKiYE
\end{abstract}

öz.

Amaç: Çalışmamızda migren tanııı konmuş hastalar ile sağııkı kontrol grubu arasında oksidatif stres, damar fizyopatolojisi ve enflamasyon biyobelirteçleri açısından bir fark olup olmadığının araşıııııması amaçlandı.

Materyal ve Metod: SBÜ Ümraniye Eğitim Araştırma Hastanesi Nöroloji Polikliniğine başvuran, 18 - 49 yaş arasında olup migren tanı kriterlerine uyan ve sistemik herhangi bir hastalığı olmayan 27 hasta ile 27 sağılılı kişiden kan ve idrar örnekleri alındı. İdrarda malondialdehit, eritrositlerde glutatyon, glutatyonla ilgili enzimler, süperoksit dismutaz, katalaz, malondialdehit ve protein karbonilleri, plazmada malondialdehit, bilirubin, ürik asit ve albümin gibi oksidatif stres biyobelirteçlerine, damar fizyopatolojisi biyobelirteçlerinden trombosit ve fibrinojene, enflamasyon biyobelirteçlerinden ise interkökin (IL) 1 $\beta$, IL6, IL10, tümör nekrozis faktör (TNF) $\alpha$, c reaktif protein (CRP) ve ferritin düzeyleri ölçüldü.

Bulgular: Hasta grubunda glutatyon ve glutatyonla ilgili enzimlerin yanında süperoksit dismutaz ve katalaz değerleri kontrol grubuna kıyasla istatistiksel olarak anlamlı düşük $(p<0,001)$ bulundu. Plazma albümin düzeylerinde gruplar arasında istatistiksel fark görülmedi. Ürik asit ve total bilirubin düzeylerinde ise hasta grubundaki düzeyler istatistiksel olarak anlamlı yüksek $(p<0,001)$ bulundu. Benzer șekilde oksidatif hasar belirtecleri olan protein karbonilleri ile plazma, eritrosit ve idrar malondialdehit düzeyleri hasta grubunda istatistiksel olarak anlamlı yüksek $(p<0,001)$ bulundu. Damar fizyopatolojisi belirteçlerinden trombosit sayısı ve fibrinojen düzeylerinin hasta grubunda anlamlı olarak arttı̆̆ı $(p<0,001)$ gözlendi. Enflamasyon belirteçlerinden IL1 1 , IL6, IL10 ve TNF $\alpha$ düzeyleri hasta grubunda istatistiksel olarak anlamlı yüksek $(p<0,001)$ bulunurken, CRP ve ferritin düzeyleri düşüktü.

Sonuç: Migren hastalarında oksidatif stres, damar fizyopatolojisi ve enflamasyon belirteçleri birlikte değerlendirildiğinde, hastalardaki baskılanan ve azalan antioksidan düzeylerinin oksidatif stresi arttırdığı dolayısılla enflamasyon ve damar fizyopatolojisi değişikliklerine neden olduğu sonucuna varıldı.

Anahtar kelimeler: Damar Fizyopatolojisi, Enflamasyon, Migren, Oksidatif Stres

Abstract

Background: We compared oxidative stress, vascular pathophysiology, and inflammation markers of migraine patients with healthy volunteers.

Materials and Methods: Blood and urine samples were obtained from 27 healthy individuals and 27 patients with a diagnosis of migraine who applied to Neurology Outpatient Clinics of Umraniye Research and Training Hospital. Participants were aged between $18-49$ years. Patients had their diagnosis established prior to the study, and the volunteers in the control group had no systemic disease or relevant disorders. Urine samples were tested for malondialdehyde while erythrocytes were investigated for glutathione, glutathione related enzymes, superoxide dismutase, catalase, malondialdehyde, and protein carbonyls. Plasma samples were analyzed for malondialdehyde, bilirubin, uric acid, and albumin as oxidative stress parameters. Thrombocyte count and fibrinogen levels were measured for vascular physiopathology, and interleukin (IL)1B, IL6, IL10, tumor necrosis factor (TNF) $\alpha$, CRP, and ferritin were used as inflammation markers.

Results: In addition to glutathione and glutathione-related enzymes, superoxide dismutase and catalase values were found to be statistically significantly lower $(p<0.001)$ in the patient group. Albumin levels were similar in both groups, whereas uric acid and bilirubin levels were significantly higher $(p<0.001)$ in the patient group. Similarly, protein carbonyls, which are oxidative damage markers, as well as urine, plasma, and erythrocyte malondialdehyde levels were significantly higher $(p<0.001)$ in the patient group. Thrombocyte count and fibrinogen levels, both of which are vascular physiopathology markers, were found to increase in the patient group $(p<0.001)$. The participants in the patient group had significantly higher $(p<0.001)$ levels of IL1 $\beta$, IL6, IL10, and TNF $\alpha$ as inflammation markers, on the other hand, CRP and ferritin levels were lower.

Conclusions: Considering oxidative stress, vascular physiopathology, and inflammation markers as a whole, we suggest that patients with migraine had increased oxidative stress due to suppressed and decreased levels of antioxidants and consequently had inflammatory and vascular changes.

Key Words: Vascular Physiopathology, Inflammation, Migraine, Oxidative Stress
Corresponding Author/Sorumlu Yazar

Dr. Eray Metin GÜLER

Sağlık Bilimleri Üniversitesi Hamidiye Tıp Fakültesi Tıbbi Biyokimya A.B.D.

Üsküdar, İstanbul, TÜRKIYE

E-mail: eraymetinguler@gmail.com

Received / Geliş Tarihi: 21.02.2120

Accepted / Kabul Tarihi: 17.03.2021

DOI: $10.35440 /$ hutfd. 883824

Makalemiz Eray Metin Güler'in yüksek lisans tezinden üretilmiştir. Ayrıca, 6-11 Temmuz 2013 tarihinde gerçekleşen Federation of European Biochemical Societies Congress toplantısinda "The Role of Oxidative / Antioxidative Balance, Vascular Pathophysiology and Inflammation in Migraine" başlıklı poster olarak sunulmuștur. 


\section{Giriş}

Uluslararası Baş Ağrısı Derneği (IHS)'nin yapmış olduğu sınıflandırmaya göre birincil baş ağrıları arasında gösterilen migren, genel olarak, nörojenik enflamasyon, kraniyal kan damarlarının kontraktil disfonksiyonları ve serebral korteksden başlayıp yayılım gösteren depresyon mekanizmalarının rol oynadığı, gastrointestinal ve/veya otonomik rahatsızııların eşlik ettiği epizodik bir baş ağrısı ile karakterize olan yaygın bir kronik hastalıktır (1). Dünya Sağlık Örgütü’ne göre, migren tipi baş ağrısı erkeklerde en çok görülen ilk 10 hastalık içindeyken, kadınlarda en sık görülen ilk beş hastalık arasında yer almaktadır (2). Çeşitli çalışmalarda migren patogenezinden nöroenflamatuvar durumlar, sitokinler, bazı nöropeptitler ve vazomotor değişiklikler sorumlu tutulmuştur (3).

Öte yandan, reaktif oksijen türlerinin üretimi ile antioksidan savunma mekanizmaları arasındaki dengesizlik nedeniyle ortaya çıkan oksidatif stres, migren dâhil çeşitli baş ağrısı bozukluklarında rol oynamaktadır (4). Artmış oksidatif stres DNA ile lipitler, karbohidratlar ve proteinlerde oksidatif hasara neden olabilir (5). Migrenin artmış oksidatif stresle ilişkili olabileceğine dair kanıtlar vardır. Bununla birlikte, oksidatif stresin migren patofizyolojisi üzerindeki etkisi, mevcut çalışmaların sayısı sınırlı olduğundan ve veriler kısmen çelişkili olduğundan hala net değil$\operatorname{dir}(6)$.

Son yıllarda migren patogeneziyle ilgili çeşitli teoriler öne sürülmüştür. Bunların başında vasküler teori ve migren ağrısı aşırı duyarlılığı yer almaktadır. Migren, nörojenik enflamasyona bağlı vazodilatasyon ve kan-beyin bariyeri geçirgenliği ile ilişkilidir. Migrendeki patofizyolojik mekanizmalardan birinin aşırı nitrik oksit üretimi olduğu bilinmektedir (7). Ayrıca migren artık birincil nörovasküler bir hastalık olarak kabul edilmektedir. Klinik olarak etkilenen bölgeye karşılık gelen korteksteki serebral kan akışının göreceli olarak azalmasıyla tetiklenir ve ardından gelişen reaktif hiperemi, steril enflamasyon ve ağrı yollarının aşırı duyarlılaşmasının yanı sıra trombosit sayısındaki artış, fibrinojen ve fibrinojen reseptörlerindeki anormalliklerle de ilişkilidir (8).

Migren araştırmalarının bir başka odağı enflamasyonun olası rolüdür. Migrendeki kronikliğin altında yatan mekanizmalar tam çözülmemesine rağmen, artmış enflamasyonun patogenezi etkilediği varsayılmaktadır (9). Kronik migrene yol açan migren sıklığındaki artışın, trigeminovasküler sistemin nöronlarında ve glial hücrelerde protein kinazların aktivasyonu yoluyla sitokinlerin artan ekspresyonunu gerektiren nörojenik nöroenflamasyonu kapsadığı ileri sürülmektedir (3).

Çalışmamızda migren patofizyolojisini etkileyen bu kadar çok mekanizmayı bir arada ele alarak, enflamasyon, oksidatif stres ve damar fizyopatolojisinin etiyolojideki rolünü aydınlatmak istedik. Bu amaçla migren hastalarında ve aynı demografik özellikteki sağlıklı kişilerde malondialdehit, protein karbonilleri, süperoksit dismutaz, katalaz, glu tatyon, glutatyon peroksidaz, glutatyon S-transferaz, bilirubin, ürik asit ve albümin gibi oksidatif stres belirteçleri ile damar fizyopatolojisi parametrelerinden trombosit ve fibrinojen ve enflamasyon parametrelerinden IL1 $\beta$, IL6, IL10, TNF $\alpha$, CRP ve ferritin düzeyleri incelendi.

\section{Materyal ve Metod}

Çalışmamıza Haziran 2012 - Mayıs 2013 tarihleri arasında Sağlık Bilimleri Üniversitesi Ümraniye Eğitim ve Araştırma Hastanesi Nöroloji Polikliniği'nde migren tanısı konmuş 18-49 yaş arası hastalar ile aynı demografik özelliklere sahip sağlıklı gönüllüler dâhil edildi. Her gruptaki gönüllü sayısı, glutatyon düzeyleri baz alınarak yapılan güç analizi ile $\alpha=0.05$ anlamlılık düzeyinde $\% 80$ güç elde edecek şekilde en az 25 kişi olacak şekilde hesaplanmıştır. Toplamda çaIışmaya her bir grup için 25 kadın 2 erkek dâhil edilmiştir. Çalışma için gerekli etik kurul onayı Marmara Üniversitesi Tıp Fakültesi Girişimsel Olmayan Klinik Araştırmalar Kurulu'ndan B.30.2.MAR.0.01.02/AEK/167 numaralı kararla alınmıştır. Her grubu oluşturan bireyler ile projenin amacı ve kapsamını açıklayıcı bilgilendirme görüşmesi yapılıp, aydınlatılmış onam belgesi alınmıştır. Çalışmaya dâhil edilen tüm hastalar ve sağlıklı gönüllüler için yaş, cinsiyet, meslek, yandaş hastalıklar, sigara içme durumları, almakta oldukları tedaviler gibi bilgileri içeren olgu kayıt formu doldurularak kaydedilmiştir. Hem hasta hem de sağlıklı kontrol grubunda hipertansiyon, böbrek fonksiyon bozukluğu, diyabet, kronik kalp hastalıkları, kollajen doku hastalıkları, endokrinolojik ve romatolojik hastalıkları olanlar ile enfeksiyonu olanlar, gebelik ve emzirme döneminde olanlar ve başka kronik nörolojik hastalıkları olanlar çalışmadan çıkarılmıştır.

\section{Örnek hazırlama}

Çalışmaya dâhil edilen hasta ve sağlıklı gönüllülerden oksidatif stres, enflamasyon ve damar fizyopatolojisi biyobelirteçlerinin ölçümü için sabah 07:00 ile 11:00 arasında kan ve idrar örnekleri alınmıştır. Alınan kan örnekleri lityum heparinli tüpe alınıp 3000 g'de 10 dakika santrifüj edildikten sonra plazmaları ayrılmıştır. Kalan eritrosit pelleti izotonik tuzlu su ile yıkanıp $\beta$-merkaptoetanol ile muamele edilmiş, hemoglobin konsantrasyonu ölçüldükten sonra eritrosit hemolizatı hazırlanmıştır (10). Alınan idrar örnekleri soğuk zincirde tutulmuş, 24 saat içinde çalışımıştır.

\section{Oksidatif stres biyobelirteçleri}

Oksidatif stres biyobelirteçlerinden eritrosit glutatyon (GSH) düzeyleri Mannervik ve Guthenberg'in (11), glutatyon redüktaz (GR) aktivitesi Beutler'in (10), glutatyon peroksidaz (GPx) aktivitesi Beutler'in (10), glutatyon S-transferaz aktivitesi Habig, Pabst ve Jakoby'nin (12), katalaz (CAT) aktivitesi Beutler'in (10), süperoksit dismutaz (SOD) aktivitesi Sun, Oberley ve Li'nin (13), malondialdehit (MDA) düzeyleri Stocks, Modell ve Dormandy'nin (13) 
yöntemlerine göre hazırlanan protokole uygun olarak ölçülmüştür. Plazma protein karbonil düzeyleri Levine ve arkadaşlarının (14), plazma malondialdehit düzeyleri Ohkawa, Ohishi ve Yagi'nin (15), idrar malodialdehit düzeyleri Hua ve Akihiko'nun (16) protokollerine göre ölçülmüştür. Plazma albümin, total bilirubin ve ürik asit düzeyleri Beckman Coulter (AU480) biyokimya otoanalizöründe ölçülmüştür.

\section{Damar fizyopatoloji biyobelirteçleri}

Damar fizyopatolojisi biyobelirteçlerinden plazma fibrinojen düzeyleri tam otomatik koagülasyon analiz cihazında (Amax 200), tam kan trombosit düzeyleri ise hemogram cihazında (Abbott CellDyn Ruby) ölçülmüştür.

\section{Enflamasyon biyobelirteçleri}

Plazma interlökin 1 beta (IL1 $\beta$; Lot: ab100562, Abcam, $A B D$ ), interlökin 6 (IL6; Lot: ab100573, Abcam, ABD), interlökin 10 (IL10; Lot: ab46034, Abcam, ABD), tümör nekroz faktör alfa (TNF $\alpha$; Lot: ab181421, Abcam, ABD) düzeyleri ticari ELISA kitleri ile fotometrik olarak, plazma ferritin ve $C$ reaktif protein (CRP) düzeyleri ise biyokimya otoanalizörü (Abbott Architech ci16200) ile ölçülmüştür (17).

\section{istatistiksel analiz}

Elde edilen veriler "SPSS (Statistical Program for Social Sciences) for Windows 17.0" istatistik paket programıla analiz edildi. İstatistiksel analiz öncesinde her gruptaki verilerin normal dağılıp dağılmadığını değerlendirmek için Kolmogrov Smirnov testi yapıldı. Her 2 gruptaki tüm değişkenlerin dağılımı normal olduğundan, gruplar arasındaki karşılaştırmalarda "bağımsız grupların ortalama karşılaştırması, t-testi” kullanılmış, anlamlılık düzeyi 0.05 olarak alınmıştır.

\section{Bulgular}

Çalışma gruplarının demografik özelliklerine bakıldığında, hasta ve kontrol grupları arasında cinsiyet (25K-2E; 25K$2 \mathrm{E})$ ve ortalama yaş $(38.11 \pm 8.39 ; 37.85 \pm 7.97)$ açısından anlamlı bir farklılık gözlenmedi.

Migren tanısı konmuş hastalar ile sağlıklı kontrol grubundan elde edilen oksidatif stres biyobelirteçleri sonuçları Tablo 1'de damar fizyopatolojisi biyobelirteçleri sonuçları Tablo 2'de ve enflamasyon biyobelirteçleri sonuçları Tablo 3'de verilmiştir.

Antioksidanlardan glutatyon, glutatyon S-transferaz, glutatyon peroksidaz, glutatyon redüktaz, süperoksit dismutaz ve katalaz aktivitesi hasta grubunda sağlıklı gruba göre istatistiksel olarak anlamlı düşük $(p<0,001)$ bulunmuştur. Her iki grupta albümin ve ürik asit düzeyleri arasında istatistiksel olarak anlamlı fark bulunamamıştır. Oksidatif hasar biyobelirteçlerinden protein karbonilleri, plazma malodialdehit, eritrosit malondialdehit ve idrar malondialdehit düzeyleri hasta grubunda sağlıklı gruba göre istatistiksel olarak anlamlı yüksek ( $p<0,001$ bulunmuştur).
Tablo 1. Migren tanısı konmuş hastalar ile sağııkı kontrol grubunda oksidatif stres biyobelirteçleri

\begin{tabular}{|c|c|c|c|}
\hline \multicolumn{4}{|c|}{ ERITROSIT ANTIOKSIDANLARI } \\
\hline & $\begin{array}{l}\text { KONTROL } \\
\text { Ort } \pm S S\end{array}$ & $\begin{array}{l}\text { HASTA } \\
\text { Ort } \pm \text { SS }\end{array}$ & $p$ \\
\hline $\begin{array}{l}\text { Glutatyon } \\
\text { ( } \mu \mathrm{mol} / \mathrm{g} \mathrm{Hb})\end{array}$ & $6,84 \pm 0,39$ & $4,75 \pm 0,44$ & 0,0001 \\
\hline $\begin{array}{l}\text { Transferaz } \\
\text { (nmol ürün/mL) } \\
\text { Glutatyon }\end{array}$ & $47,59 \pm 6,52$ & $22,80 \pm 5,03$ & 0,0001 \\
\hline $\begin{array}{l}\text { Peroksidaz } \\
\text { (U/g Hb) } \\
\text { Glutatyon }\end{array}$ & $153,07 \pm 10,53$ & $42,93 \pm 10,48$ & 0,0001 \\
\hline $\begin{array}{l}\text { Redüktaz } \\
(\mathrm{U} / \mathrm{g} \mathrm{Hb})\end{array}$ & $6,43 \pm 1,37$ & $2,81 \pm 0,98$ & 0,0001 \\
\hline $\begin{array}{l}\text { Süperoksit } \\
\text { Dismutaz } \\
\text { (U/g Hb) }\end{array}$ & $\begin{array}{l}2016,98 \quad \pm \\
480,94\end{array}$ & $\begin{array}{l}1172,37 \quad \pm \\
186,92\end{array}$ & 0,0001 \\
\hline $\begin{array}{l}\text { Katalaz } \\
(\mathrm{U} / \mathrm{gHb})\end{array}$ & $827,26 \pm 113,30$ & $308,11 \pm 51,34$ & 0,0001 \\
\hline \multicolumn{4}{|c|}{ PLAZMA ANTIOKSIDANLARI } \\
\hline $\begin{array}{l}\text { Albümin } \\
\text { (g/dL) }\end{array}$ & $4,18 \pm 0,42$ & $4,15 \pm 0,30$ & 0,766 \\
\hline $\begin{array}{l}\text { Ürik Asit } \\
\text { (mg/dL) }\end{array}$ & $3,53 \pm 0,85$ & $4,24 \pm 0,79$ & 0,0003 \\
\hline $\begin{array}{l}\text { Total Bilirubin } \\
(\mathrm{mg} / \mathrm{dL})\end{array}$ & $0,31 \pm 0,10$ & $0,49 \pm 0,19$ & 0,0001 \\
\hline \multicolumn{4}{|l|}{ OKSIDATIF HASAR } \\
\hline $\begin{array}{l}\text { Protein } \\
\text { Karbonilleri } \\
\text { (nmol/mg protein) } \\
\text { Plazma }\end{array}$ & $67,42 \pm 8,18$ & $112,89 \pm 7,68$ & 0,0001 \\
\hline $\begin{array}{l}\text { Malondialdehit } \\
\text { (nmol/mL) } \\
\text { Eritrosit }\end{array}$ & $0,19 \pm 0,09$ & $0,69 \pm 0,15$ & 0,0001 \\
\hline $\begin{array}{l}\text { Malondialdehit } \\
\text { (nmol MDA/g Hb) } \\
\text { İdrar }\end{array}$ & $178,97 \pm 46,55$ & $328,08 \pm 42,05$ & 0,0001 \\
\hline $\begin{array}{l}\text { Malondialdehit } \\
(\mathrm{nmol} / \mathrm{mL})\end{array}$ & $0,20 \pm 0,06$ & $1,72 \pm 0,28$ & 0,0001 \\
\hline
\end{tabular}

Tablo 2. Migren tanısı konmuş hastalar ile sağııkı kontrol grubunda damar fizyopatolojisi biyobelirteçleri

\begin{tabular}{llll}
\hline \multicolumn{4}{l}{ DAMAR FiZYOPATOLOJISI BIYOBELIRTEÇLERI } \\
\hline & $\begin{array}{l}\text { KONTROL } \\
\text { Ort } \pm \text { SS }\end{array}$ & $\begin{array}{l}\text { HASTA } \\
\text { Ort } \pm \text { SS }\end{array}$ & $p$ \\
$\begin{array}{l}\text { Fibrinojen } \\
(m g / d L)\end{array}$ & $233,59 \pm 8,86$ & $305,30 \pm 33,02$ & 0,0001 \\
$\begin{array}{l}\text { Trombosit } \\
(K / \mu L)\end{array}$ & $186,52 \pm 8,65$ & $274,37 \pm 29,07$ & 0,0001 \\
\hline
\end{tabular}

Damar fizyopatolojisi biyobelirteçlerinden fibrinojen ve trombosit düzeyleri hasta grubunda kontrol grubuna göre istatistiksel olarak anlamlı yüksek $(p<0,001)$ bulunmuştur. Enflamasyon biyobelirteçlerinden IL1 $\beta$, IL6, IL10, TNF $\alpha$, CRP ve ferritin düzeyleri hasta grubunda kontrol grubuna kıyasla istatistiksel olarak anlamlı derecede yüksek $(p<0,001)$ bulunmuştur. 
Tablo 3. Migren tanısı konmuş hastalar ile sağııkı kontrol grubunda enflamasyon biyobelirteçleri

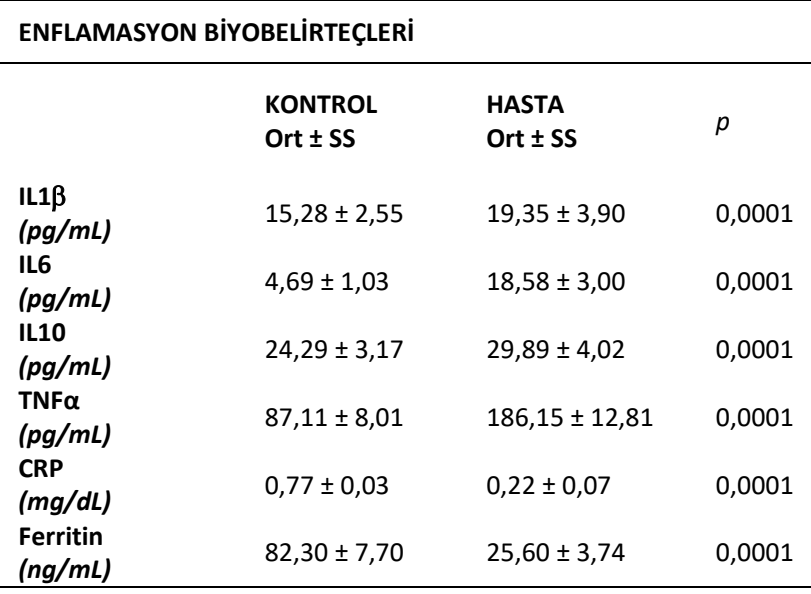

\section{Tartışma}

Migren, kortikal uyarılabilirlik, nöroenflamasyon ve vasküler duvar disfonksiyonundaki değişikliklerin patofizyolojisine katkıda bulunduğu yaygın bir hastalıktır. Tahmini migren prevalansı, nüfusun $\% 12$ ile $\% 16$ 'sı arasındadır ve kadınlarda erkeklerden daha yüksektir (18). Migren patofizyolojisi ile ilgili çok sayıda çalışma olmasına rağmen, migrenin altında yatan rahatsızlıkların moleküler mekanizması hala tam olarak bilinmemektedir (17).

Mevcut teoriler, reaktif oksijen türlerinin üretim ve yıkım dengesindeki bozukluklar sonucu ortaya çıkan oksidatif strese büyük önem vermektedir. Serbest radikallerin neden olduğu oksidatif stres ve oksidatif hasarın kanser, kardiyovasküler hastalıklar, diyabet, nörodejeneratif hastalıklar gibi birçok patofizyolojik sürecin erken evrelerinde önemli rol oynadığı bilinmektedir. Elde edilen sonuçlar oksidatif stresin migren patolojisinde önemli bir rol oynadığını ve düzeyi düşen antioksidanların da etkisinin olduğunu ortaya koymuştur. Oksidanlar fazla miktarda üretildiğinde ya da bu moleküllerin regülasyonunda rol alan antioksidan mekanizmalarda fonksiyon kaybı olduğunda oksidatif stres meydana gelmektedir. Oksidatif stresin DNA, membran lipitleri, enzimler ve yapısal proteinler gibi biyomoleküllerin oksidasyonu yoluyla hücrelerdeki onarım kapasitelerinin aşılması ve zarar görmesi ile karakterize bir durum olduğu bilinmekle birlikte, bu durumun migren de olmak üzere birçok hastalığın gelişiminde rol oynadığı düşünülmektedir (19). Oksidanlar, bazı antioksidan enzimler ile enzimatik olmayan antioksidanlar tarafından etkisiz hale getirilmektedir. Antioksidan enzimlerin başlıca örnekleri, süperoksit dismutaz, katalaz, glutatyon peroksidaz ve peroksiredoksinlerdir. Enzimatik olmayan antioksidanların başlıcaları, her ikisi de endojen olarak üretilen glutatyon ve ubikinon (koenzim Q10) ile sadece diyetle alınan askorbik asit, $\alpha$-tokoferol ve beta karotendir. Bunlardan glutatyon hücrelerde enzimatik olmayan ana antioksidan olarak ön plana çıkmaktadır (20). Glutatyon genel olarak tiyol (R-SH) içeren proteinleri oksidasyondan korur ve hücrelerde glutatyon redüktaz enzimi tarafından rejenere edilir. Yapılan çalışmada, oksidatif stresin migren patogenezinde önemli rol oynadığına inanılmaktadır (21). Gyanesh ve arkadaşlarının oksidatif stres belirteçlerinin migrendeki rolü ve tedavinin etkisi konulu araştırmalarında, migren hastalarında glutatyon ve glutatyon S-transferaz seviyelerinin önemli ölçüde azaldığı gözlenmiştir (22). Oksidatif stres uzun dönemde migren oluşumuna zemin hazırlayan önemli bir faktör olabilir. Çalışmamızda migren hastalarının antioksidan düzeyleri sağlıklı kontrollere kıyasla anlamlı derecede düşük, oksidatif hasar parametreleri ise anlamlı derecede yüksek bulunmuştur. Benzer şekilde oksidatif hasar belirteçleri olan protein karbonilleri ile plazma, eritrosit ve idrar malondialdehit düzeyleri hasta grubunda anlamlı yüksek bulunmuştur. Manyetik rezonans ölçümlerinde görülen yüksek yoğunluklu beyaz cevher veya ailede migren öyküsü olan bazı migren hastalarında serumda azalmış katalaz aktivitesinin hidrojen peroksit detoksifikasyonunda sorunlar çıkarabileceği ileri sürülmüştür (23). Bununla birlikte, migrenli hastalarda eritrositlerde ve trombositlerde daha düşük süperoksit dismutaz aktivitesi bulunmuş, eritrositlerde glutatyon peroksidaz seviyeleri ve serumda oksitlenmemiş tiyol konsantrasyonları ile toplam antioksidan kapasitede azalma olduğu da rapor edilmiştir (24). Bütün bunlardan oksidan mekanizmaların beyinde endojen olarak işlediği anlaşılmaktadır. Çeşitli migren tetikleyicilerinin (dehidrasyon, aşırı ışık, ses veya koku yoğunluğu, hipoglisemi, uykusuzluk vb.) ortak noktalarından birinin oksidatif stresi artırma kapasiteleri olduğu düşünülmektedir. Bu düşünce, artmış oksidatif veya nitrozatif stres ve/veya azalmış antioksidan kapasite belirteçlerinin gözlendiği çalışmalarla desteklenmektedir. Bununla birlikte migrende oksidatif stres ve/veya antioksidan kapasite ile ilgili olarak yapılan çalışmada en az bir biyobelirtecin anormal seviyelerde olduğu gösterilmiştir (22). Incelenen tüm biyobelirteçler arasında migren hastalarında özellikle süperoksit dismutaz aktivitesi sürekli olarak azalmış gibi görünmektedir ki bu da bizim sonuçlarımızla paralellik göstermektedir (7). Diğer belirteçler için gözlenen farklılıklar ve tutarsız sonuçlar, metodoloji farklılıkları, hasta seçim kriterleri ve migren döngüsü ile ilgili varyasyonlardan kaynaklanabilir.

Öte yandan, vasküler enflamasyonun, akut migren sürecinin önemli bir parçası olduğu varsayılmaktadır (25). Migrenin damar fizyopatolojisi ile ilgili çalışmalardan elde edilen son bilgiler, bu durumun birincil bir nörovasküler bozukluk olarak değerlendirilmesi gerektiğini göstermektedir. Patogenez serebral kan akışında göreceli bir azalma ile sürdürülür, bunu daha sonra reaktif hiperemi, steril iltihaplanma ve ağrı yollarının aşırı duyarlılığı takip eder. Migrenin en temel karakterize özelliği zonklayıcı tipte baş ağrısıdır. Bunun da genellikle trigeminovasküler yolak üzerindeki ağrı sinyallerinden kaynaklandığı düşünülmektedir (26). Hastaların \% 30'unda oluşan auranın da eşlik ettiği migren tipinin, özellikle iskemik inme için bir risk faktörü 
olduğu düşünülmektedir. Bu ilişkinin altında yatan muhtemel sebepler vardır. Özellikle kadın hastalarda, premenopoz dönemlerinde herhangi bir kardiyovasküler risk bulunmamasına rağmen inme görülme riski erkeklere nazaran daha fazladır. Bu bulgu aterosklerozun migren ile ilişkili olmadığını öne süren çalışmalar ile örtüşmekte ve migren-inme ilişkisinde aterosklerozun ön planda olmadığı savını güçlendirmektedir (27). Genel popülasyondaki inmenin aksine, migrenle ilişkili inme çalışmalarının meta analizi, bu durumun en yaygın olarak gençlerde, özellikle kadınlarda ve hatta yaş yelpazesi genelinde, düşük vasküler risk profiline sahip kişilerde daha yaygın olduğunu göstermektedir (28). Bu bulgular, migrenle ilişkili inmelerin doğası gereği aterosklerotik olmadığını göstermektedir. Aterosklerozun fonksiyonel ve yapısal özelliklerinin migrende daha yaygın olmadığını gösteren çalışmalar mevcuttur (27). Trombositler, kanın esas olarak hemostazda yer alan hücresel elementleridir. Trombosit fonksiyonları, adhezyon, agregasyon ve vasküler ton modifikasyonlarında rol alan çeşitli faktörlerin salgılanmasını, trombüs oluşumunu ve son olarak plazmadan serotonin ve amino asitlerin alımını içerir (29). Çalışmamızda damar fizyopatolojisi parametrelerinin hasta grubundaki düzeyleri kontrol grubuna göre anlamlı yüksek bulunmuştur. Migrendeki sistemik enflamasyon, damar fizyopatolojisinin ve oksidatif stresin kolaylaştırıcı faktörü olabilir. Ancak bu parametreler sadece migren oluşumunu, migren atağı şiddetini, atak sayısını ve migren komplikasyonlarının oluşumunu etkiliyor olabilir. Trombositlerin migren patogenezindeki rolü yapılan çalışmalarla giderek aydınlatılmaktadır. Metodolojilerde ve kullanılan gereçlerdeki farklılıklardan dolayı trombosit-migren çalışmalarından alınan sonuçlar çeşitlilik göstermektedir. Bizim sonuçlarımızla paralel bir şekilde, bir kısım çalışmalar migren atağında trombosit aktivasyonunun arttığını rapor etmiş (30), diğer çalışmalarda ise ataklar sırasında trombosit aktivasyonunun azaldığı bildirilmiştir (31). Oral kontraseptiflerin kullanımının da migren hastası kadınlarda inme riskini artırması hiperkoagülasyonun önemli bir rol oynayabileceğini düşündürmektedir (32). Hiperkoagülasyon-migren tandemi migrenin hem tetikleyicisi hem de sonucu olabilen stres durumu ile ilişkilendirilmiştir. Stresin bağışıklık, kardiyovasküler, endokrin ve otonom sistem üzerinde etkileri bulunmaktadır. Akut stresin prokoagülan moleküllerin (fibrinojen, faktör XII, faktör VII vb.) seviyesini fibrinolizdeki miktarlardan daha fazla artırdığı gözlenmiştir (33). Kronik streste hiperkoagülasyonu tetikleyebilmektedir. Derin ven trombozu oluşturulan sıçan modellerinde maruz kalınan kronik stresin kanda trombosit agregasyonunu ve oksidatif stres biyobelirteçlerini artırdığı bildirilmiştir (34). Fibrinojen bir plazma glikoproteini ve fibrin öncülü olup trombosit agregasyonunda, lökosit-endotel hücre ilişkisinde endotel hasarında ve plazma viskozitesinde rol oynamaktadır. Fibrinojenin migrendeki rolünü inceleyen çalışmalar sınırlıdır. Yalnızca bir çalışmada migren ile ilişkili fibrinojen artışı görülmediği rapor edilmiş (35), diğer çalışmalarda bizim sonuçlarımızla paralel bir şekilde migrenli kadınlarda kontrollü oral kontraseptif kullanımından sonra bile fibrinojen seviyesinin arttığı bildirilmiştir (36). Migren çalışmalarının bir diğer odak noktası enflamasyonun olası rolüdür. Genellikle kemirgenler ile yapılan çalışmalar özellikle nörojenik enflamasyonun migren patofizyolojisindeki önemini vurgulamıştır. Bununla birlikte akut migren ataklarında enflamasyonun rolünün çok fazla olmadığı da ortaya çıkarmıştır. Bu bağlamda P maddesi reseptör antagonistlerinin efikasi eksikliği öne çıkmaktadır $(37,38)$. Ağrı oluşmasında immün sistem önemli bir rol oynamaktadır. TNF $\alpha$, IL1, IL6, NGF (nöron büyüme faktörü) ve prostaglandin E2 (PGE2)'nin ağrı oluşumu mekanizmasında etkileri vardır. Bu enflamatuvar maddelerin ağrı ve hiperaljezi oluşturdukları gösterilmiştir. Proenflamatuvar sitokinlerin (IL1 $\beta$, TNF $\alpha$ ) ve antienflamatuvar sitokinlerin (IL2, IL4, IL10, IL13) trigeminal sinir sensitizasyonunda ve ağrı eşiğinin düzenlenmesinde önemli rollere sahip oldukları bildirilmiştir (39). Perini ve arkadaşlarının migrende sitokinlerin rolünü aydınlatma amacıyla yaptığı bu çalışmada, migrenlilerde atak ve ataklar arası dönemde plazmada proenflamatuvar (IL1 $\beta$, TNF $\alpha$ ) ve antienflamatuvar sitokinler (IL2, IL4, IL10, IL13) için ayrı ayrı paneller oluşturulmak suretiyle ölçümler yapılmıştır. Auralı ve aurasız migrenli hastalar arasında farklı sonuçlar bulunmuş ancak IL6, IL4, IL2 seviyelerinde auralı ve aurasız olgularda fark bulunamamıştır. Çalışmamızda ise hasta grubundaki IL6 ve IL10 düzeyleri kontrol grubuna göre anlamlı derecede yüksek bulunmuştur. Perini'nin çalışmasında da IL10, TNF $\alpha$ ve IL1 $\beta$ düzeyleri atak esnasında ataklar arası evreye göre yüksek bulunmuştur. Fidan ve arkadaşları (40) TNFa ve IL1 düzeylerinde migrenliler ve sağlıklı kontrol grubu arasında önemli bir fark bildirmemişler, buna karşın bizim yaptığımız çalışmada hasta grubunun TNF $\alpha$ ve IL1 $\beta$ düzeyleri kontrol grubuna göre hem yüksek hem de istatistiksel açıdan anlamlı bulunmuştur. Çalışmalar arasında farklılıkların fazla olması sitokinlerin hormonal durumdan etkilenmesinden ya da sitokin salınımlarının diürnal ritm göstermesinden kaynaklanabilir. TNF $\alpha$, IL1 $\beta$, IL6 gibi ana sitokinler migren patofizyolojisi ile ilişkilendirilmiş olup bu patoloji ile seviyeleri değişebilmektedir (41). Yapılan çalışmalarda plazma, kan veya idrar TNF $\alpha$ seviyeleri migren hastalarında atak sırasında ve ataklar arası dönemde değişimler göstermiş, bu da hastalarda enflamasyonun varlığını düşündürmüştür (38). İnsanda serumda artan TNF $\alpha$ seviyeleri, atak döneminde değilken bile TNF $\alpha$ 'nın migrendeki patojenik rolünü desteklemektedir (42). Bir başka araştırma migren atakları sırasında serumda artan IL1 $\beta$, IL6 VE TNF $\alpha$ seviyeleri olduğunu göstermiş, atak sırasında jugular vende IL6 ve TNF $\alpha$ 'nın arttığı da bildirilmiştir (43). Migren atakları sırasında başta TNF $\alpha$ olmak üzere sitokin seviyelerinde değişimlerin meydana geldiği gösterilmiş olmasına rağmen bu durumun migren patofizyolojisi ile olan ilişkisi halen tartışmalıdır. Migrenin sık görülen, yıpratıcı ve uzun yıllar süren bir hastalık olduğu göz önüne 
alındığında, enflamasyonun uzun dönemde hastalığın patolojisinde gözle görülen bir iz bırakması beklenir, fakat çalışmalarda böyle bir bulguya rastlanamamıştır (44).

Migren patogenezinin aydınlatılması için çok sayıda çaIışma yapılmış olmasına rağmen kullanılabilecek olası biyobelirteçler aynı hastalarda değerlendirilip kapsamlı bir şekilde incelenmemiştir. Bulgularımıza göre hastalarda antioksidan kapasitenin azalması oksidatif stresi indüklemekte, artmış oksidatif stres vücuttaki enflamasyon ve koagülasyon süreçlerini etkilemektedir. Sonuç olarak, çaıışmamızdan elde edilen bulgular migrene zemin hazırlayan faktörlerin belirlenmesinde ve mevcut tedavi protokollerinin geliştirilmesinde yol gösterici olabilir.

Etik onam: Çalışmamı 12.01.2011 tarihinde Marmara Üniversitesi Tıp Fakültesi Girişimsel Olmayan Klinik Araştırma Etik Kurulu'nca 09.2011.0188 protokol numarası,

B.30.2.MAR.0.01.02/AEK/167 sayı numarası ile onaylanmıştır. Yazar Katkıları:

Konsept: A.S.Y., E.M.G.

Literatür Tarama: E.M.G., A.S.Y.

Tasarım: A.S.Y., A.D.Y.

Veri toplama: H.G.P., Ü.A.K., A.K., E.M.G.

Veri analizi ve yorumlama: A.K., E.M.G., A.S.Y.

Makale yazımı: E.M.G., A.S.Y.

içeriğin eleştirel incelenmesi: A.D.Y., Ü.A.K., H.G.P.

Çıkar Çatışması: Yazarlar herhangi bir çıkar çatışması olmadığını beyan eder.

Finansal Destek: Bu tez çalışması Marmara Üniversitesi Bilimsel Araştırma Projeleri Birimi tarafından SAG-C-YLP-110412-0070 numaralı proje ile desteklenmiştir.

\section{Kaynaklar}

1. Bulboacă $A E$, Stănescu IC, Bolboacă SD, Bulboacă $A C$, Bodizs GI, Nicula CA. Retinal Nerve Fiber Layer Thickness and Oxidative Stress Parameters in Migraine Patients without Aura: A Pilot Study. Antioxidants. 2020;9(6):494.

2. Saylor D, Steiner TJ, editors. The global burden of headache. Seminars in neurology; 2018: Thieme Medical Publishers.

3. Edvinsson L, Haanes KA, Warfvinge K. Does inflammation have a role in migraine? Nature Reviews Neurology. 2019;15(8):483-90.

4. Cesarone MR, Dugall M, Hu S, Belcaro G, Hosoi M, Scipione $\mathrm{V}$, et al. Episodic primary migraine headache: supplementary prophylaxis with Pycnogenol ${ }^{\circledR}$ prevents attacks and controls oxidative stress. Panminerva medica. 2020;62(2):102-8.

5. Othmène YB, Hamdi $H$, Salem IB, Annabi E, Amara I, Neffati $\mathrm{F}$, et al. Oxidative stress, DNA damage and apoptosis induced by tebuconazole in the kidney of male Wistar rat. Chemico-Biological Interactions. 2020;330:109114.

6. Vasques MAA, Fonseca EdBM. A review on migraine and oxidative stress. Revista de Medicina e Saúde de Brasília. 2020;9(2).

7. Neri M, Frustaci A, Milic M, Valdiglesias V, Fini M, Bonassi $\mathrm{S}$, et al. A meta-analysis of biomarkers related to oxidative stress and nitric oxide pathway in migraine. Cephalalgia. 2015;35(10):931-7.

8. Danese $\mathrm{E}$, Montagnana M, Lippi G. Platelets and migraine.
Thrombosis research. 2014;134(1):17-22.

9. Lukacs M, Tajti J, Fulop F, Toldi J, Edvinsson L, Vecsei L. Migraine, neurogenic inflammation, drug development-pharmacochemical aspects. Current medicinal chemistry. 2017;24(33):3649-65.

10. Beutler E. Red cell metabolism. A manual of biochemical methods. 1975:11-2.

11. Mannervik B, Guthenberg C. [28] Glutathione transferase (human placenta). Methods in enzymology. 77: Elsevier; 1981. p. 231-5.

12. Habig WH, Pabst MJ, Jakoby WB. Glutathione S-transferases: the first enzymatic step in mercapturic acid formation. Journal of biological Chemistry. 1974;249(22):7130-9.

13. Sun Y, Oberley LW, Li Y. A simple method for clinical assay of superoxide dismutase. Clinical chemistry. 1988;34(3):497-500.

14. Levine RL, Garland D, Oliver CN, Amici A, Climent I, Lenz A$\mathrm{G}$, et al. [49] Determination of carbonyl content in oxidatively modified proteins. Methods in enzymology. 1990;186:464-78.

15. Ohkawa H, Ohishi N, Yagi K. Assay for lipid peroxides in animal tissues by thiobarbituric acid reaction. Analytical biochemistry. 1979;95(2):351-8.

16. Zhou H, Kato A, Miyaji T, Yasuda H, Fujigaki Y, Yamamoto $T$, et al. Urinary marker for oxidative stress in kidneys in cisplatin-induced acute renal failure in rats. Nephrology Dialysis Transplantation. 2006;21(3):616-23.

17. Guler EM, Gokce M, Bacaksiz A, Kocyigit A. Urotensin-II, oxidative stress, and inflammation increase in hypertensive and resistant hypertensive patients. Clinical and Experimental Hypertension. 2020:1-6.

18. Burch RC, Buse DC, Lipton RB. Migraine: epidemiology, burden, and comorbidity. Neurologic clinics. 2019;37(4):63149.

19. Halliwell B, Gutteridge JM. Free radicals in biology and medicine: Oxford University Press, USA; 2015.

20. Abdel-Salam OM, Salem NA, Hussein JS. Effect of aspartame on oxidative stress and monoamine neurotransmitter levels in lipopolysaccharide-treated mice. Neurotoxicity research. 2012;21(3):245-55.

21. Bockowski L, Sobaniec W, Kulak W, Smigielska-Kuzia J, Bockowski L, Sobaniec W, et al. Serum and intraerythrocyte antioxidant enzymes and lipid peroxides in children with migraine. Pharmacological reports. 2008;60(4):542.

22. Tripathi GM, Kalita J, Misra UK. A study of oxidative stress in migraine with special reference to prophylactic therapy. International Journal of Neuroscience. 2018;128(4):31824.

23. Aytaç B, Coşkun Ö, Alioğlu B, Durak ZE, Büber S, Tapçi E, et al. Decreased antioxidant status in migraine patients with brain white matter hyperintensities. Neurological Sciences. 2014;35(12):1925-9.

24. Bolayir E, Celik K, Kugu N, Yilmaz A, Topaktas S, Bakir S. Intraerythrocyte antioxidant enzyme activities in migraine and tension-type headaches. JOURNAL-CHINESE MEDICAL ASSOCIATION. 2004;67(6):263-7.

25. Williamson DJ, Hargreaves RJ. Neurogenic inflammation in the context of migraine. Microscopy research and technique. 2001;53(3):167-78.

26. Noseda R, Burstein R. Migraine pathophysiology: anatomy of the trigeminovascular pathway and associated neurolo- 
gical symptoms, cortical spreading depression, sensitization, and modulation of pain. PAIN ${ }^{\circledR}$. 2013;154:S44-S53.

27. Stam $A H$, Weller $C M$, Janssens $A C J$, Aulchenko YS, Oostra $B A$, Frants RR, et al. Migraine is not associated with enhanced atherosclerosis. Cephalalgia. 2013;33(4):228-35.

28. Schürks $M$, Rist PM, Bigal ME, Buring JE, Lipton RB, Kurth $T$. Migraine and cardiovascular disease: systematic review and meta-analysis. Bmj. 2009;339.

29. Tietjen GE, Collins SA. Hypercoagulability and migraine. Headache: The Journal of Head and Face Pain. 2018;58(1):173-83.

30. Jha S, Varma M, Garg R, Kar A. Platelet aggregation in migraine. The Journal of the Association of Physicians of India. 1992;40(3):153-4.

31. D'andrea G, Cananzi A, Perini F, Alecci M, Zamberlan F, Hasselmark $L$, et al. Decreased collagen-induced platelet aggregation and increased platelet arginine levels in migraine: a possible link with the NO pathway. Cephalalgia. 1994;14(5):352-6.

32. Tepper NK, Whiteman MK, Zapata LB, Marchbanks PA, Curtis KM. Safety of hormonal contraceptives among women with migraine: a systematic review. Contraception. 2016;94(6):630-40.

33. Von Känel R, Mills PJ, Fainman C, Dimsdale JE. Effects of psychological stress and psychiatric disorders on blood coagulation and fibrinolysis: a biobehavioral pathway to coronary artery disease? Psychosomatic medicine. 2001;63(4):531-44.

34. Dong $T$, Cheng $Y-W$, Yang $F$, Sun $P-W$, Zhu C-J, Zhu L, et al. Chronic stress facilitates the development of deep venous thrombosis. Oxidative medicine and cellular longevity. 2015;2015.

35. Kurth $T$, Ridker $P$, Buring J. Migraine and biomarkers of cardiovascular disease in women. Cephalalgia. 2008;28(1):4956.

36. Tietjen GE, Khubchandani J, Herial N, Palm-Meinders IH, Koppen $\mathrm{H}$, Terwindt GM, et al. Migraine and vascular disease biomarkers: a population-based case-control study. Cephalalgia. 2018;38(3):511-8.

37. Peroutka SJ. Neurogenic inflammation and migraine: implications for the therapeutics. Molecular interventions. 2005;5(5):304.

38. Diener H. RPR100893, a substance-P antagonist, is not effective in the treatment of migraine attacks. Cephalalgia. 2003;23(3):183-5.

39. Perini F, D'Andrea G, Galloni E, Pignatelli F, Billo G, Alba S, et al. Plasma cytokine levels in migraineurs and controls. Headache: The Journal of Head and Face Pain. 2005;45(7):926-31.

40. Fidan I, Yüksel S, Ýmir T, İrkeç C, Aksakal FN. The importance of cytokines, chemokines and nitric oxide in pathophysiology of migraine. Journal of neuroimmunology. 2006;171(1-2):184-8.

41. Johnson KW, Bolay $\mathrm{H}$. Neurogenic inflammatory mechanisms: Lippincott, Williams \& Wilkins, PA, USA; 2006.

42. Tanure MTA, Gomez RS, Hurtado RCL, Teixeira AL, Domingues RB. Increased serum levels of brain-derived neurotropic factor during migraine attacks: a pilot study. J Headache Pain. 2010;11(5):427-30.

43. Yücel M, Kotan D, Gurol Çiftçi G, Çiftçi I, Cikriklar H. Serum levels of endocan, claudin-5 and cytokines in migraine. Eur Rev Med Pharmacol Sci. 2016;20(5):930-6.
44. Goadsby PJ, Holland PR, Martins-Oliveira M, Hoffmann J, Schankin C, Akerman S. Pathophysiology of migraine: a disorder of sensory processing. Physiological reviews. 2017. 